\title{
Resistance to Anti-infectious Chemotherapies: Risk Factors for Extensively Drug-resistant Strains in Hospitalized Patients
}

\author{
DELIA IOANA HORHAT ${ }^{1}$, DELIA MUNTEAN2*, SMARANDA ARGHIRESCU ${ }^{3 *}$, SIMONA CERBU ${ }^{4}$, DANIELA IACOB ${ }^{5}$, \\ FLORIN GEORGE HORHAT ${ }^{2}$ \\ IVictor Babes University of Medicine and Pharmacy, Department of ENT, 2 Eftimie Murgu Sq., 300041, Timisoara, Romania \\ ${ }^{2}$ Victor Babes University of Medicine and Pharmacy, Department of Microbiology, 2 Eftimie Murgu Sq., 300041, Timisoara, \\ Romania \\ ${ }^{3}$ Victor Babes University of Medicine and Pharmacy, Department of Paediatrics, 2 Eftimie Murgu Sq., 300041, Timisoara, Romania \\ ${ }^{4}$ Victor Babes University of Medicine and Pharmacy, Department of Radiology, 2 Eftimie Murgu Sq., 300041, Timisoara, Romania \\ ${ }^{4}$ Victor Babes University of Medicine and Pharmacy, Department of Neonatology, 2 Eftimie Murgu Sq., 300041, Timisoara, \\ Romania
}

\begin{abstract}
This retrospective study was conducted between January 2016 and March 2016 in the Pius Brinzeu County Emergency Clinical Hospital of Timi'oara. Data were collected from the electronic database of the laboratory and the hospital's electronic medical records. The purpose of this study was to identify risk factors for extensivelydrug-resistant (XDR) bacteria. The results obtained suggest that the catheterization, endotracheal intubation and previous antibiotic therapy or the prolonged hospitalization may be risk factors for the acquisition of XDR strains.
\end{abstract}

Keywords: cephalosporins, aminoglycosides, fluoroquinolones

At a time when bacterial multi-resistance is a daily reality, where the degree of therapeutic invasiveness of modern medicine is steadily increasing, with an increasing number of patients with comorbidity or immunosuppression, attention is directed to prevention and tackling risk factors [1].

\section{Experimental part}

\section{Inclusion / exclusion criteria}

This retrospective observational study included 2,465 patients hospitalized between January 2016 and March 2016 at the Pius Brinzeu Emergency Clinical Hospital Timisoara. The study group included 55 patients, from whom XDR strains were isolated upon admission. The control group consisted of 2410 patients, these patients were free of XDR infection and were hospitalized for the same period of time. Patients who were under 18 years of age or with pre-hospital infections were excluded.

\section{Data collection}

The information was collected from the hospital's digital records.

Potential risk factors were: main diagnosis, invasive medical factors, and previous use of broad spectrum antiinfectious chemotherapies.

\section{Statistical analysis}

The statistical analysis of the database obtained from this study was carried out using EPI-INFO version 3.2.2 and SPSS version 10.0. The numerical variables characterized by mean and standard deviation were tested by the Kolmogorov-Smirnov test. The numerical variables with normal distribution were compared to the unpaired $t$ test, for the dichotomic type the Chi-square test was used and the Fischer corrections were calculated. All statistical tests were calculated with 2 extremes and the value of statistical significance $p$ was taken into account at values d" 0.05 .

\section{Bacteriologic diagnosis}

Pathological products from current clinical work were processed in the hospital lab. The Vitek 2 Compact system (BioMerieux, France) was used to identify and test the susceptibility to anti-infectious chemotherapies. Extensively drug-resistant strains (XDR) included those bacteria that remained sensitive to at least two classes of antibacterial substances.

\section{Results and discussion}

The study comprised 55 XDR strains, representing a prevalence of $2.23 \%$, relative to the number of patients hospitalized in that period. In figure 1, most XDR strains are represented by Acinetobacter baumannii ( 33 strains $60 \%$ of the total XDR), followed by Providencia stuartii (11 strains - 20\%), Klebsiella pneumoniae (6 strains - 10.9\%), Staphylococcus aureus (2 strains-3.63\%), Serratia marcescens, Proteus mirabilis and Pseudomonas aeruginosa with one strain each (1.81\%).

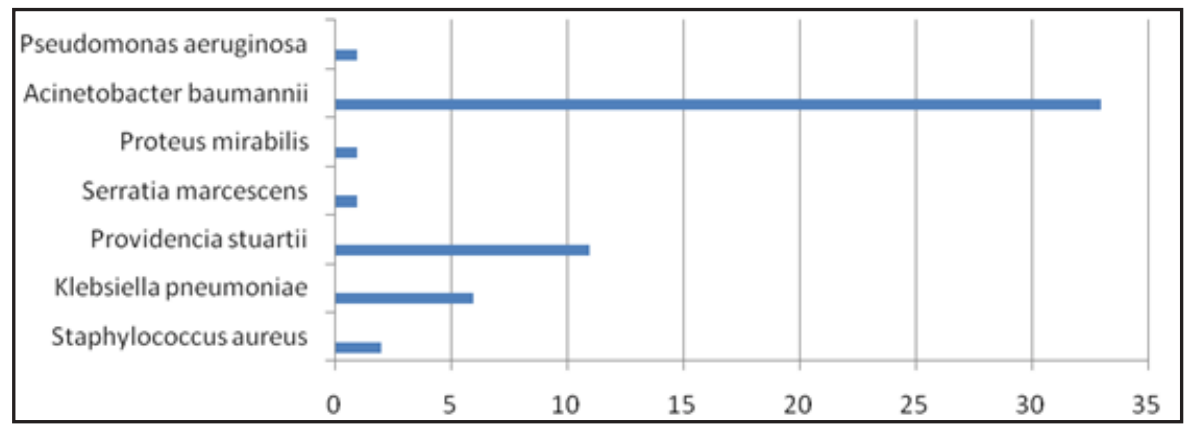

*email: muntean.delia@umttro; sarghirescu@yahoo.com
Fig. 1 Distribution by species of XDR strains 
Table 1

EVOLUTION OF INFECTIONS CAUSED BY XDR BACTERIA

\begin{tabular}{|c|c|c|}
\hline Characteristics & & Nr. (\%) patients \\
\hline Fever & Yes & $42(76.4)$ \\
\cline { 2 - 3 } & No & $13(23.6)$ \\
\hline Leukocytosis & Yes & $36(65.5)$ \\
\hline $\begin{array}{c}\text { Positive } \\
\text { inflammatory tests }\end{array}$ & No & $19(34.5)$ \\
\hline Favorable evolution & Yes & $49(89.1)$ \\
& No & $6(10.9)$ \\
\hline & & $32(58.2)$ \\
\hline
\end{tabular}

The characteristics of the 55 patients from whom the XDR strains were isolated are shown in table 1.

As shown in Table 1, the number of cases with favourable evolution is lower than those with unfavourable evolution, these findings were supported by other researchers $[14,75,76]$.

Statistically, we did not notice significant differences between the two sexes in the presence of XDR strains. They were associated with more frequent presence of comorbidities represented by (table 2): surgical pathology $(p<0.001)$, diabetes mellitus $(p<0.001)$ and neurological pathology ( $p=0.003)$. These results are concurrent with the findings of other studies that included neurological pathology and diabetes [2-4] among the risk factors associated with multi-resistant bacteria.

The group of patients with XDR-induced infections was associated with a younger age and a longer duration of hospitalization (60.4 years versus 79.4 years, $p<0.001$ and 67.2 days vs. 44.2 days respectively, $p<0.001$ ). In the study conducted by Bellissimo-Rodrigues et al., young age was identified as a risk factor for resistant strains [5]. The number of admission days has been associated with resistance, and in other studies, it is considered that the risk for multi-resistance is directly proportional to the duration of hospitalization $[2,3,6]$.

We also analysed the values of invasive manoeuvres and observed that there were significantly higher values in the duration of maintenance of endotracheal intubation $(1,3$ days vs. 1,0 days $p=0,001$ ) and central venous catheter ( 6,0 days vs. 5,2 days, $p=0,021$ ). Additionally, the duration of previous anti-biotherapy (12.3 days vs. 9.6 days, $p$ $<0.001$ ) was prolonged in patients from whom XDR strains were subsequently isolated (table 3 ). Such a result is consistent with that reported by other researchers who have shown the role of vesicular catheterization, endotracheal intubation, mechanical ventilation, central venous catheterization and surgical interventions or the total number of days of antibiotic therapy in acquiring antibiotic resistance [6-12]. Numerous studies focus on the potential risk of antibiotic therapy in selecting multidrug-resistant strains, associating this phenomenon with the use of third generation cephalosporins [13-20], fluorochinolones $[8,9]$, aminoglycosides or trimethoprimsulfamethoxazole $[9,10]$.

\begin{tabular}{|c|c|c|c|c|}
\hline & & XDR absent & XDR present & $\mathbf{p}$ \\
\hline \multirow[t]{2}{*}{ Sex } & Male & $1080(97.6 \%)$ & $26(2.4 \%)$ & \multirow{2}{*}{0.784} \\
\hline & Female & $1330(97.9 \%)$ & $29(2.1)$ & \\
\hline \multirow{2}{*}{$\begin{array}{l}\text { Cardiovascular } \\
\text { pathology }\end{array}$} & No & $296(99.3 \%)$ & $2(0.7 \%)$ & \multirow{2}{*}{0.057} \\
\hline & Yes & $2114(97.6 \%)$ & $53(2.4 \%)$ & \\
\hline \multirow[t]{2}{*}{ Surgical pathology } & No & $1858(98.4 \%)$ & $31(1.6 \%)$ & \multirow{2}{*}{$<0.001$} \\
\hline & $Y_{\text {es }}$ & $552(958 \%$ & $24(1204)$ & \\
\hline & & & & \\
\hline \multirow[t]{2}{*}{ Digestive pathology } & No & $1236(98.3 \%)$ & $21(1.7 \%)$ & \multirow{2}{*}{0.057} \\
\hline & Yes & $1174(97.2 \%)$ & $34(2.8 \%)$ & \\
\hline \multirow[t]{2}{*}{ Oncological pathology } & No & $2249(97.9 \%)$ & $49(2.1 \%)$ & \multirow{2}{*}{0.268} \\
\hline & Yes & $161(96.4 \%)$ & $6(3.6 \%)$ & \\
\hline \multirow[t]{2}{*}{ Diabetes } & No & $2039(99.2 \%)$ & $17(0.8 \%)$ & \multirow{2}{*}{$<0.001$} \\
\hline & Yes & $371(907 \%)$ & $38(93 \%)$ & \\
\hline \multirow{3}{*}{ Neurological pathology } & & & $8(1004$ & \\
\hline & No & $801(99.0 \%)$ & & \multirow{2}{*}{0.003} \\
\hline & Yes & $1609(97.2 \%)$ & $47(2.8 \%)$ & \\
\hline \multirow[t]{2}{*}{ Respiratory pathology } & No & $2363(97.8 \%)$ & $53(2.2 \%)$ & \multirow{2}{*}{0.299} \\
\hline & Yes & $47(95.9 \%)$ & $2(4.1 \%)$ & \\
\hline
\end{tabular}

Table 2

CHARACTERISTICS OF PATIENTS WITH INFECTIONS PRODUCED BY XDR BACTERIA 


\begin{tabular}{|c|c|c|c|}
\hline & XDR absent & XDR present & $\mathbf{p}$ \\
\hline Age (years) & $79.4 \pm 30.3$ & $60.4 \pm 29.1$ & $<0.001$ \\
\hline $\begin{array}{l}\text { Length of hospitalization } \\
\text { (days) }\end{array}$ & $44.2 \pm 27.6$ & $67.2 \pm 40.9$ & $<0.001$ \\
\hline $\begin{array}{l}\text { Duration of peripheral } \\
\text { venous catheter } \\
\text { maintenance (days) }\end{array}$ & $8.6 \pm 1.7$ & $8.9 \pm 2.0$ & 0.270 \\
\hline $\begin{array}{l}\text { Duration of central venous } \\
\text { catheter maintenance } \\
\text { (days) }\end{array}$ & $5.2 \pm 1.8$ & $6.0 \pm 2.5$ & 0.021 \\
\hline $\begin{array}{l}\text { Duration of urinary } \\
\text { catheterization (days) }\end{array}$ & $29.9 \pm 6.5$ & $29.8 \pm 8.0$ & 0.923 \\
\hline $\begin{array}{l}\text { Duration of endotracheal } \\
\text { intubation (days) }\end{array}$ & $1.0 \pm 0.7$ & $1.3 \pm 0.8$ & 0.001 \\
\hline $\begin{array}{l}\text { Duration of previous } \\
\text { antibiotherapy (days) }\end{array}$ & $9.6 \pm 8.3$ & $12.3 \pm 9.4$ & 0.018 \\
\hline
\end{tabular}

Table 3

CHARACTERISTICS OF THE PARAMETERS STUDIED IN PATIENTS WITH AND WITHOUT INFECTIONS CAUSED BY XDR BACTERIA

\section{Conclusions}

Surgical, neurological and metabolic pathology, along with the presence of the central vascular catheter, endotracheal intubation and previous anti-biotherapy, were more commonly associated with XDR bacterial infections. In addition, patients from whom XDR strains were isolated required prolonged hospitalization compared to other patients.

\section{References}

1.MUNTEAN, D., LICKER, M., Current Topics in Intensive Care Medicine: Infections and Multidrug-Resistant Pathogens in ICU Patients, ed.: IntechOpen. 2018.

2.WASHER, L.L., DePESTEL, D.D., HALM, M., et al. http://www.sheaonline.org/Assets/files/Multi-Resistant_GramNegative Bacteria.doc.pdf

3.APISARNTHANARAK, A., KIRATISIN, P., SAIFON, P., et al. Am. J. Infect. Control., 35, 9, 2007. p. 606-612.

4.MOOR, C.T., ROBERTS, S.A., SIMMONS, G., et al. J. Hosp. Infect., 68 , 4, 2008. P. 355-362.

5.BELLISSIMO-RODRIGUEZ, F., GOMES, A.C., PASSOS, A.D., etal. Mem. Inst. Oswaldo Cruz, 101, 4, 2006. p. 415-421.

6.KUHAR, D., CALFEE, D., http://www.shea-online.org/Assets/files/ Multi-Resistant_Gram-Negative_Bacteria.doc.pdf

7.SCHIAPPA, D.A., HAYDEN, M.K., MATUSHEK, M.G., et al. J. Infect. Dis., 174,1996. p. 529-536.

8.WIENER, J., QUINN,J.P., BRADFORD, P.A., et al. JAMA, 281,1999. p. 517-523.
9.LAUTENBACH, E., PATEL, J.B., BILKER, W.B., et al. Clin. Infect. Dis., 32, 2001. p. 1162-1171.

10.ASENSIO, A., OLIVER, A., GONZALEZ-DIEGO, P., et al. Clin. Infect. Dis., 30, 2000. p. 55-60.

11.LUTHER, V.P., SMITH, Z.E., VARELA, V., et al. http://www.sheaonline.org/Assets/files/Multi-Resistant_GramNegative Bacteria.doc.pdf

12.BISSON, G., FISHMAN, N.O., PATEL, J.B., et al. Infect. Control. Hosp. Epidemiol., 23, 2002. p. 254-260.

13.DU, B., LONG, Y., LIU, H., et al. Intensive Care Med., 28, 2002. p. 1718-1723.

14.EVEILLARD, M., SCHMIT, J.L., EB, F., Infect. Control Hosp. Epidemiol., 23, 2002. p. 155-158.

15. HO, P.L., CHAN, W.M., TSANG, K.W., et al. Scand. J. Infect. Dis., 34, 2002. p. 567-573.

16. KIM, B.N., WOO, J.H., KIM, M.N., et al. J. Hosp. Infect., 52, 2002. p. 99-106.

17.LEE, S.O., LEE, E.S., PARK, S.Y., et al. Infect. Control. Hosp. Epidemiol., 25, 2004. p. 832-837.

18.PATERSON, D.L., KO, W.C., VON GOTTBERG, A., et al. Ann. Intern. Med., 140, 2004. p. 26-32.

19.MUNTEAN, D., LICKER, M., HORHAT, F., et al. Infect. Drug. Resist., 11, 2018. p. 2187-2197.

20.MOGHNIEH, R., SIBLANI, L., GHADBAN, D., et al. J. Hosp. Infect., 92, 2016. p. 47-53.

Manuscript received: 29.07.2018 